\title{
Automation and Robotics In Construction
}

An Overview of $R \& D$ in the United Kingdom

\author{
Dr Fikry K Garas \\ Taylor Woodrow Construction \\ Southall, Middlesex, U.K.
}

\section{In facing demands for higher productivity and improved quality the U.K. Construction Industry has been active in $\mathrm{R} \& \mathrm{D}$ in the area of automation and computer integrated} construction.

Attention has been given to the application of Information Technology to the construction process and in particular in integrating the functions of design, construction and management. Progress has also been made in developing automated tools and systems in many applications and some of the work has reached a mature stage for practical applications.

\section{INTRODUCTION}

The U.K. Construction industry plays an important role in the British economy and in spite of the current recession the value of construction output represents more than 10 per cent of the Gross Domestic Product. Normally, the industry employs about 5 per cent total working population.

Generally, investment in R \& D and new technology in the U.K. construction industry is tightly constrained because it operates in an environment that is intensely competitive and vulnerable to significant periodic fluctuations in workload. Decision makers in that industry are often faced with crucial decisions on the strategic development of new technology within their organisations.

However, the introduction of Information Technology to the design and construction process, coupled with the adoption of some automated systems, is taking momentum and is bound to have considerable effect on U.K. construction practice. Some of the ongoing research activities in the U.K. are part of pan-European Collaborative programmes.

\section{THE U.K. ADVANCED ROBOTICS INITIATIVE}

The Advanced Robotics Programme, initiated in 1985, with the support of the Department of Trade and Industry (DTI) has reached a critical stage.(1) Project Definition Studies carried out in six application areas were completed during 1990/91 followed by the preparation of a number of project proposals for implementation. 
Two projects in the tunnelling area, one in the civil Engineering Sector, led by Lilley Construction Ltd. and the other in the mining sector, led by the Caledonion Mining Company Ltd., are in progress.

The collaborative project led by Lilley Construction, is concerned with improving the efficiency and safety of tunneliing and exploits an opportunity provided by a tunnelling contract in the civil engineering area for field trials. It involves robotic systems for segment erection and grouting of the tunnel walls and complex machine condition monitoring techniques. Collaborators in the project are Lilley Construction (lead), North-West Water Ltd., Moog Controls, James Howden Ltd. and ERA Technology.

The mining project aims for a substantial increase in tunnelling advance rate in mines, by replacing existing discontinuous cutting and roof support systems with a continuous system. It involves an innovative temporary roof support robot that "walks" in pace with a cutting machine, provided with a sensor driven robotic control system for semi-autonomous tunnelling within a coal seam. Collaborators are Caledonian Mining and Moog Controls, with sub-contractors British Coal and Cambridge University.

The work on the wall climbing robot, by the Construction Group, led by Taylor Woodrow, has been delayed for financial reasons. The Collaborative Group includes W.S. Atkins, Tirfor Ltd., National Engineering Laboratory, Lancaster and Reading Universities. The robot development will be based on a modular approach, applied to both hardware and software It is anticipated that the work will commence in the second half of this year.

(2) The three year programme for the Wall Climbing Advanced Robot (2) will include the development of four demonstrators which will become available for trials after 18 months and integration to a working prototype system taking place in the third year. The four demonstrations are:

A - a mobile suspended frame with an advanced control and navigation system.

B - A manipulator-arm able to operate from the suspended frame.

C - An integrated inspection tool (and associated data handling and knowledge base) to attach to the manipulator arm.

D - A stablising system able to search and locate suitable adhesion sites for the robot frame so that the arm can be positioned for the inspection tasks.

In 1988, the Advanced Robotic Research Centre (ARRC) at Salford (3), has developed its core programme, which was designed to address the issue of designing robots that could operate in unstructured environments with emphasis on the automatic control of these systems. This programme has resulted in the lab-scale demonstration of the ability of robot systems to operate autonomously in unstructured environments, together with impressive developments in associated technologies. 
The programme included Advanced Robotic functional architecture, manipulator general purpose controller and free ranging mobiles concentrating on the capabilities required for an indoor truly free ranging Automatic Guided Vehicle (AGV). The ARRC has also participated in the work of some of the National collaborative groups.

\section{ROBOT FOR MASONRY CONSTRUCTION}

At the City University, London, research work continues to develop the enabling technology for automating masonry tasks within quality assurance environment. The research programme, which is mainly funded by the science and Engineering Research Council will be reported at the 9 th ISARC Symposium (4). The main functions of masonry construction were simulated in an experimental robot cell comprising a gantry type robot which operates the grippers, material conveyor and the laster beacon.

The robot has been assisted by supplementary navigation system to improve its positioning function. It is intended that a future cell will be developed in which a mobile robot will replace the experimental gantry. In the experimental trials a construction of a dry wall was simulated as no provision was made for a mortar dispensing function, yet to be developed.

The results so far have been encouraging with emphasis on quality control, in particular in the assessment of the supply material.

\section{4 . \\ AUTOMATION AND ROBOTS FOR INSPECTION TASKS}

Work on the inspection robot for nuclear reactors (5), at the Polytechnic of Portsmouth, is progressing with the construction of three prototypes. The robot is joystick driven and pneumatically actuated. It is controlled via a 50 metre cable by operators $30 \mathrm{~m}$ away. It is $800 \mathrm{~mm}$ long by $600 \mathrm{~mm}$ wide and $150 \mathrm{~mm}$ high and moves on eight non jointed legs with suction cup feet. Using two frames with four feet mounted on each, it moves by disengaging one set of feet whilst the other set adheres. It carries lights and two cameras and can haul a payload of $25 \mathrm{~kg}$. The robot is designed to climb about $10 \mathrm{~m}$ from the equator of the $20 \mathrm{~m}$ diameter spherical reactor pressure vessel. Attempss to automate the inspection functions for tall buildings are the subject of research work at the City University, London $(6 \& 7)$. Experimental work on the use of a robot for automatic rebar location has shown that good accuracy can be achieved. The technique adopted in the experiments is based on the use of a surface sensing head in conjunction with the rebar locating probe. Experimental work is also dealing with robot access by means of a suspended support vehicle. 
5 .

\section{ROBOT EXCAVATOR}

At Lancaster University (8) significant advances have been made in the automation excavation project. The technology has been successfully transferred from a fifth scale laboratory model to a real JCB 801 mini-excavator.

A simple operator interface allows the depth of a required trench to be input. The machine then takes over and digs a high quality flat-bottomed trench. To allow for variable ground conditions, a high-level rule-based software manager, adapting the behaviour of the machine to suit the ground conditions, has been used. Field trials have shown that the machine can cope with a very wide range of soil types including hard boulder clay.

\section{SOIL STABLISING MACHINE}

The automation of soil stablising process (9) for embankments and cuttings application has been successfully achieved by the research team at the University of Wales College of Cardiff. The system known as "Soil Nailing" which is now commercially operational, provide soil strengthening by launching long reinforcing nails into the ground by compressed air.

\section{APPLICATION OF INFORMATION TECHNOLOGY}

Traditionally, the flow of information between organisations and disciplines has almost been exclusively on paper with very little use of electronically transmitted computer based information. However, the gradual introduction of stand alone software packages, dealing with specific operations of the construction process, has made significant impact to the culture and environment of the industry. A recent report produced for the U.K. National Economic Development Council suggests that the adoption of IT and electronic data exchange could cut overall building costs by between 15 and 25 per cent with similar or greater gains in productivity.

At the University of Nottingham (10) work has been in progress in 'Automation of Management Functions' and is moving closer to 'robot intelligence'. Research work includes: automatic generation and evaluation of plans and schedules, automatic budgeting and network generation and layout optimision of building services.

As part of the Eureka initiative, the U.K. is participating in the CIMSTEEL Project (EU130) which is aiming at improving the efficiency and competitiveness of the European Constructional steelwork industry in world markets. The project goal is to integrate all the activities in the life-cycle of steel structures including design, detailing, specifications, purchasing, fabrication, erection and maintenance. 
As part of the CEC Esprit 3 programme, a collaborative project 'ATLAS' dealing with the application of IT to Large Scale Engineering projects (LSE), will concentrate on the development of a common, open platform for the integration of LSE applications, and also will aim at enhancing a number of available application tools. The participating members of the two IT vendors (Siemens and IEZ) of Germany, two $R \&$ D organisations, CSTB of France and TNO of Netherlands and two end users, Centunion of spain and Taylor Woodrow as a co-ordinating partner. The duration of the programme is three years, commencing May this year

\section{ACKNOWLEDGEMENTS}

I wish to acknowledge the invaluable assistance in the development of this paper from my colleagues in the U.K. special thanks are due to the Department of Trade and Industry for their support in preparing this paper.

\section{References}

1. Private Communication with Mr.Mike Grimmett of the Department of Trade and Industry.

2. Proposal by the Collaborative Group Civil Engineering and Construction, July 1991.

3. Private Communication with Professor John Gray of the Advanced Robotic Research Centre.

4. Chamberlain, D.A. and el 'Masonry Construction by an experimental robot', 9th ISARC, June 1992.

5. Private Communication with Arthur Collie of Portsmouth Polytechnic.

6. Chamberlain, D.A., 'A Rebar Detection Robot', 9th ISARC, June 1992 .

7. Wong, T.C.K. and Chamberlain, D.A., 'Essential Factors In the Automation of Tall Building Inspection', 9th ISARC, JUNE 1992

8. Private Communication with Derek Seward of Lancaster University.

9. Bridle, R. and Myles, B., 'A Machine for Soil Nailing Process and Design, CEEC Seminar, Paris 1991.

10. Private Communication with Bill Askew of Nottingham University. 